ROCZNIKI PEDAGOGICZNE

Tom 12(48), numer $3-2020$

DOI: https://doi.org/10.18290/rped20123-7

RENATA KOLODZIEJCZYK

\title{
GOTOWOŚĆ NAUCZYCIELI DO PRACY W SYSTEMIE EDUKACJI WŁĄCZAJĄCEJ
}

\section{OCZEKIWANIA WOBEC NAUCZYCIELA EDUKACJI WŁĄCZAJĄCEJ}

Jesteśmy świadkami przemian w edukacji zmierzających do upowszechnienia kształcenia uczniów w systemie edukacji włączającej. Badania nad edukacją włączającą w Polsce mają już swoją historię (Cytowska, 2016). Jeśli działania zmierzające do wdrożenia idei integracji potraktować jako etap dochodzenia do inkluzji to badania w tym obszarze można podzielić na trzy okresy. Pierwszy, przed wprowadzeniem prawno-formalnych uwarunkowań kształcenia integracyjnego jeszcze przed latami dziewięćdziesiątymi (np. badania A. Hulek 1980), trzeci - po przyjęciu w 2010 r. pakietu rozporządzeń opisujących całościowe zmiany w kształceniu uczniów ze specjalnymi potrzebami edukacyjnymi oraz organizację i udzielanie im pomocy psychologiczno-pedagogicznej (Chrzanowska, 2010; 2019; Krakowiak, 2017; 2019; Gajdzica, 2013, 2019; Szumski, 2019; Jachimczak, 2019, Skibska, 2016), zaś drugi etap (zwany transformacją) lokuje się pomiędzy wspomnianymi przełomowymi działaniami reformatorskimi (Maciarz, 1992; Dryżałowska, 1997, 2007). Z badań wynika, że proces ten trwa w całej Europie i ma charakter nieodwracalny. Edukacja włączająca w niektórych szkołach w Polsce jest już rzeczywistością, natomiast w innych dość odległą ideą.

Bez wątpienia bardzo ważnym ogniwem tego procesu przemian jest nauczyciel. Jest jednym $z$ trzech kluczowych ogniw w triadzie: UCZEŃ - RODZIC - NAUCZYCIEL. Jeśli zmiany w edukacji mają przynieść pozytywne skutki,

Dr Renata KoŁodziejCZYK - adiunkt, Katedra Pedagogiki Specjalnej, Instytut Pedagogiki, Wydział Nauk Społecznych, Katolicki Uniwersytet Lubelski Jana Pawła II, adres do korespondencji: Al. Racławickie 14, 20-950 Lublin; e-mail: renata.kolodziejczyk@kul.pl; ORCID: https:// orcid.org/0000-0001-7770-3220. 
jeśli mają pozwolić doświadczyć społeczeństwu słuszności i zasadności tych zmian, to przede wszystkim należy pozyskać nauczycieli jako przekonanych, zaangażowanych i kompetentnych współtwórców i wykonawców tej koncepcji edukacji. Bez ich gotowości mentalnej i merytorycznej do realizacji działań włączających w szkołach projekt, choćby najlepszy w swych założeniach, nie ma szans powodzenia.

Dojrzewanie do gotowości w tym obszarze to proces. Pełna zgoda nauczycieli na takie rozwiązania systemowe jest możliwa tylko wtedy, gdy $\mathrm{z}$ jednej strony mentalnie zaakceptują idee inkluzji, a $\mathrm{z}$ drugiej będą przekonani o swoich kompetencjach i w praktyce zawodowej będą doświadczali satysfakcji i poczucia, że odnoszą sukcesy. W konsekwencji nabiorą przekonania, że szkoła to miejsce dla każdego ucznia, że dobrze jest zarówno dla dzieci zdrowych, jak i szczególnie uzdolnionych oraz dzieci z trudnościami i niepełnosprawnościami uczyć się w jednym zespole klasowym, ubogacając siebie wzajemnie. Jednocześnie wierząc w swoje kompetencje, zbudują poczucie samoskuteczności w kształceniu uczniów klas włączających, posiadając niezbędne w tym celu umiejętności metodyczno-organizacyjne (Europejska Agencja Rozwoju Edukacji Uczniów ze Specjalnymi Potrzebami 2012, za: Chrzanowska, Szumski, 2019b, s. 59).

Przemiany w podejściu nauczycieli w Polsce do idei inkluzji są widoczne w badaniach prowadzonych w ostatnim dziesięcioleciu (Chrzanowska, 2010, 2016. 2019a). Jeszcze w 2010 r. I. Chrzanowska (2010, s. 36-42) wymienia jako jeden z nurtujących edukację problemów brak rzeczywistych i konstruktywnych postaw zrozumienia i akceptacji dla wspólnego kształcenia uczniów z niepełnosprawnością i pełnosprawnych. Wyniki badań tej samej autorki opisane w 2019 r. (2019a, 2019b, s. 53) dowodzą natomiast dużej zmiany mentalnej respondentów, gdyż ponad $70 \%$ badanych nauczycieli było przekonanych o skuteczności kształcenia inkluzyjnego. Tendencję tę w pewnym sensie potwierdzają też badania współautorskie, które będą prezentowane w niniejszym artykule. $Z$ tego wynika, że nauczyciele zasadniczo popierają ideę edukacji włączającej, ale widzą konkretne przeszkody i utrudnienia na tej drodze.

Jedną z głównych przeszkód wstrzymujących nauczycieli przed deklaracją gotowości do pracy w edukacji włączającej jest wizja idealnego nauczyciela edukacji włączającej, czyli świadomość konkretnych wymagań w zakresie kompetencji oraz umiejętności metodycznych i organizacyjnych, których oczekuje się od nauczyciela pracującego z grupą zróżnicowaną. Europejska Agencja Rozwoju Edukacji Uczniów ze Specjalnymi Potrzebami (2012, s. 13) 
nakreśliła profil nauczyciela edukacji włączającej, w ramach którego wskazała cztery podstawowe wartości, mające doniosłe znaczenie dla pracy wszystkich nauczycieli w placówkach włączających. Są to:

- docenianie różnorodności - różnice między uczniami uznaje się za zaletę i czynnik sprzyjający edukacji;

- wspieranie wszystkich uczniów - nauczyciele spodziewają się, że każdy uczeń dokona znaczących postępów w nauce;

- nastawienie na współpracę - wszyscy nauczyciele uznają zasadniczą rolę pracy zespołowej i współdziałania;

- indywidualny rozwój zawodowy - nauczanie opiera się na uczeniu się; nauczyciele biorą na siebie odpowiedzialność uczenia się przez całe życie.

Do zadań, kompetencji i postaw oczekiwanych od nauczyciela w pracy z grupą zróżnicowaną zalicza się:

- tworzenie w szkole właściwej atmosfery sprzyjającej budowaniu relacji;

- poznanie uczniów, ich sposobów funkcjonowania w klasie, odgrywania ról, relacji w klasie, w grupie rówieśniczej;

- rozwijanie kompetencji społecznych uczniów i kształtowanie prawidłowych relacji w heterogenicznych grupach rówieśniczych;

- poznanie sytuacji środowiskowej uczniów, problemów ich rodzin, aktywnego poszukiwania form wsparcia rodziny ucznia i udzielania wsparcia;

- świadome budowanie pozytywnego społecznego obrazu niepełnosprawnych uczniów w szkole oraz kształtowania w nich poczucia własnej wartości bez względu na trudności, których doświadczają;

- poznanie strategii uczenia się i stylów nauczania w celu ich doboru do zróżnicowanych potrzeb uczniów;

- wspieranie procesu uczenia się każdego ucznia w jego indywidualnym tempie;

- projektowanie przestrzeni klasy szkolnej, wykorzystanie odpowiednich środków i pomocy dydaktycznych, podręczników, specjalistycznych narzędzi umożliwiających realizację treści kształcenia, ich adaptacji i doboru do zróżnicowanych potrzeb uczniów;

- wdrażanie procesu motywowania podopiecznych do nauki i kształtowania pozytywnego stosunku do uczenia się;

- wykorzystanie konwencjonalnych i niekonwencjonalnych metod nauczania oraz ich adaptacji do potrzeb uczniów;

- znajomość i wykorzystywanie w praktyce wspomagających i alternatywnych metod komunikacji; 
- stosowanie szerokiego wachlarza organizacyjnych form kształcenia, w tym niekonwencjonalnych, bazujących na wzajemnym edukowaniu się uczniów i współpracy między nimi;

- monitorowanie rozwoju uczniów i efektywności własnych oddziaływań;

- reagowanie i modyfikacja działań w celu podnoszenia jakości pracy w różnicowanym zespole;

- planowanie zajęć w taki sposób, aby każdy uczeń „znalazł swoje miejsce" podczas ich trwania;

- stawianie jasnych wymagań dostosowanych do potrzeb i możliwości uczniów;

- zachęcanie ucznia, pomaganie mu i przekazywanie informacji zwrotnych umożliwiających rozwój oraz dających wsparcie i podnoszących motywację;

- pokazywanie, że każdy uczeń jest ważny;

- tworzenie przyjaznej, ciepłej atmosfery podczas zajęć;

- dawanie poczucia bezpieczeństwa poprzez akceptowanie błędów, które traktowane są jako ważny etap w procesie uczenia się;

- stawanie się dla ucznia przewodnikiem w procesie uczenia się, a nie bycie tylko przekazicielem wiedzy;

- elastyczne podejście do nauczania, dostosowanie programów nauczania, treści kształcenia do potrzeb i możliwości uczniów;

- ocenianie zróżnicowanych możliwości uczniów, zachowanie motywującej funkcji ocen, budowanie adekwatnej, ale również pozytywnej samooceny uczniów;

- opracowywanie programów wychowawczych (IPET) skoncentrowanych na potrzebach ucznia, klasy, społeczności szkolnej, a także ich koordynowanie, monitorowanie, ewaluację i modyfikację;

- gotowość do współpracy z rodzicami oraz instytucjami, które mogą wesprzeć nauczyciela $\mathrm{w}$ doskonaleniu pracy $\mathrm{z}$ uczniami o zróżnicowanych potrzebach;

- zdolność do współpracy w wielospecjalistycznych zespołach, która jest związana ze znajomością odpowiedniej terminologii i sposobów myślenia osób o różnym wykształceniu (Jachimczak, 2019, s. 150-151; Chrzanowska, Szumski, 2019, s. 60-61; Krakowiak, 2019, s. 92-100; Grygier, 2019, s. 4, 15; Szczepkowska, 2019, s. 4-5).

Do tych ogólnych zaleceń dołączyć należy specyficzne kompetencje i umiejętności przydatne w pracy z poszczególnymi grupami uczniów ze specjalnymi potrzebami edukacyjnymi. Dla przykładu - w zakresie pracy z uczniem cu- 
dzoziemskim lub z doświadczeniem migracyjnym nauczyciel powinien dysponować wiedzą i umiejętnościami w zakresie:

- psychologicznej sytuacji dziecka migrującego i jego rodziny, w tym konsekwencji uchodźstwa i migracji;

- rozumienia konsekwencji posługiwania się stereotypami w pracy z uczniami z innych kultur, a także przeciwdziałania uprzedzeniom i dyskryminacji;

- równego traktowania wszystkich uczniów, z jednoczesnym taktownym wspieraniem tych, którzy potrzebują włączenia w edukację;

- rozumienia różnic kulturowych, czym jest kultura i jaki ma wpływ na zachowanie ucznia w szkole;

- rozumienia zachowania ucznia, które może wynikać nie tylko z jego cech indywidualnych, ale też z kultury kraju, z którego przybył - norm, wartości, sposobów zachowania się, czego przejawem nie są jedynie stroje i jedzenie typowe dla różnych kultur;

- znajomości kultur pochodzenia uczniów, w tym najważniejszych tradycji i obyczajów, najważniejszych świąt, tabu kulturowego, sposobów zachowania się - np. okazywania szacunku nauczycielowi - stosunku do edukacji w kraju pochodzenia, ról kobiet, mężczyzn i dzieci;

- znajomości obowiązujących regulacji prawnych dotyczących różnych grup etnicznych, np. kim są uchodźcy, kim przedstawiciele mniejszości etnicznych i narodowych, a kim imigranci; jakie są ich prawa i obowiązki; jaka jest liczebność tych grup;

- rozumienia zjawiska akulturacji, w tym: strategii adaptacji, stresu akulturacyjnego/szoku kulturowego, adaptacji kulturowej, wyzwań dotyczących komunikacji międzykulturowej - werbalnej i niewerbalnej;

- dostosowania materiałów do potrzeb i możliwości dzieci migrujących, w tym wykorzystania metody indywidualizacji (Białek, Jarmuż, Ośko, 2015, s. 53-54).

Analizując tę długą listę wymagań, nasuwa się konkluzja, że im bardziej zróżnicowany jest zespół klasowy, tym szerszych kompetencji i umiejętności będzie potrzebował nauczyciel, aby zbudować poczucie samoskuteczności w pracy z heterogenicznymi grupami uczniów. Nauczyciele wskazują na trzy kluczowe sfery swojego działania, które pomagają zbudować takie poczucie samoskuteczności. Są to:

- efektywne kształcenie wszystkich uczniów;

- radzenie sobie z trudnymi zachowaniami podopiecznych;

- współpraca ze specjalistami i rodzicami (Sharma, Loreman, Forlin, 2011, za: Chrzanowska, Szumski 2019b, s. 60). 
Efektywne kształcenie wszystkich uczniów w grupie zróżnicowanej wiąże się z opanowaniem przez nauczyciela $\mathrm{z}$ jednej strony sztuki indywidualizacji $\mathrm{w}$ nauczaniu, z drugiej zaś projektowania uniwersalnego. Badania potwierdzają bowiem, że metody i strategie dydaktyczne skuteczne w nauczaniu uczniów bez niepełnosprawności sprawdzają się również podczas kształcenia uczniów z niepełnosprawnością. Do takich strategii zalicza się przede wszystkim: udzielanie uczniom częstych, wyczerpujących informacji zwrotnych na temat ich postępów i wzmacnianie ich motywacji do uczenia się, stosowanie metod opartych na współpracy, klarowne, dobrze ustrukturyzowane prezentowanie materiału $\mathrm{z}$ wykorzystaniem zasad uniwersalnego projektowania zajęć, umiejętne stosowanie technologii informacyjnych do indywidualizowania nauczania i upoglądowienia materiału, a także efektywne zagospodarowanie czasu lekcji (Mitchell 2016; Vaughn, Gersten, Chard 2000, za: Chrzanowska, Szumski 2019b, s. 61)

Aby wyposażyć nauczyciela $\mathrm{w}$ te niezbędne kompetencje i umiejętności, potrzeba $\mathrm{z}$ jednej strony zapewnić profesjonalne przygotowanie kandydatów do zawodu nauczyciela $w$ ramach realizowanych studiów wyższych, a następnie zapewnić szeroką ofertę studiów podyplomowych, kursów i szkoleń, w ramach których aktywni zawodowo nauczyciele mogliby uzupełniać swoje kwalifikacje, zdobywać nowe umiejętności i kompetencje. Nauczyciele nie mogą jednak pozostać osamotnieni w realizacji tak odpowiedzialnych i wymagających zadań. Należy stworzyć dla nich zarówno instytucjonalną, jak i nieinstytucjonalną sieć wsparcia, która dawałaby możliwość pracy $\mathrm{w}$ zespole specjalistów, współdecydowania, wymiany doświadczeń.

Poniżej zaprezentowano wyniki fragmentu współautorskich badań przeprowadzonych przez zespół pedagogów (R. Kołodziejczyk, A. Borowicz, A. Tomaszewska) w 2019 r. wśród ponad 700 nauczycieli różnych typów szkół i poziomów edukacji. Badania dotyczą opinii nauczycieli na temat kształcenia uczniów ze specjalnymi potrzebami edukacyjnymi w edukacji włączającej oraz doświadczanych przez nich trudności i potrzeb na drodze do realizacji skutecznej inkluzji. Na potrzeby niniejszego artykułu autorka dokonała analizy odpowiedzi na wybrane pytania badawcze. Przytoczone analizy mają charakter wstępnego raportu z badań, które nadal są kontynuowane. Po zakończeniu badań zgromadzony materiał posłuży do bardziej szczegółowej analizy zależności i korelacji w obrębie poszczególnych grup respondentów, uwzględniając różnorodne czynniki. 


\author{
II. GOTOWOŚĆ NAUCZYCIELI DO PRACY \\ W EDUKACJI WŁĄCZAJĄCEJ - ANALIZA BADAŃ WŁASNYCH
}

\title{
1. Metoda, technika i narzędzie badawcze
}

Do badań została wybrana metoda sondażu diagnostycznego oraz technika ankiety. Narzędzie badawcze w formie kwestionariusza ankiety zostało opracowane przez zespół pedagogów w składzie: R. Kołodziejczyk, A. Borowicz, A. Tomaszewska. Kwestionariusz składał się z 24 pytań, w tym 6 o charakterze metryczki osoby badanej, 10 pytań zamkniętych, 7 pytań otwartych oraz jednego zadania składającego się z 13 twierdzeń, do których respondent miał się ustosunkować według pięciostopniowej skali, gdzie 5 oznaczało „całkowicie się zgadzam”, a 1 - „całkowicie się nie zgadzam”.

\section{Procedura badawcza i charakterystyka grupy badanej}

Ankieta została udostępniona do wypełnienia przez formularz Google w terminie od 4 listopada 2019 r., a dane do niniejszej analizy zostały zaczerpnięte dnia 4 grudnia 2019 r., po miesiącu dostępności ankiety. Ankieta jest nadal aktywna i sukcesywnie wzrasta liczba respondentów, dzięki czemu jest możliwość uzupełniania i aktualizowania wyników. Informacja o możliwości udziału w badaniach docierała do nauczycieli za pośrednictwem niektórych kuratoriów oświaty, Lubelskiego Samorządowego Centrum Doskonalenia Nauczycieli i mediów społecznościowych. W badaniach do 4 grudnia 2019 r. wzięło udział 774 nauczycieli z całej Polski. Do wypełnienia ankiety zostali zaproszeni nauczyciele/pedagodzy pracujący w szkołach ogólnodostępnych i integracyjnych, niemniej jednak w grupie osób badanych znaleźli się również nauczyciele i pedagodzy specjalni ze szkół i ośrodków specjalnych (101 osób). Grupa badawcza z założenia miała być zróżnicowana. Bardzo różna jest lokalizacja placówek oświatowych, w których pracowali respondenci. Zdecydowaną większość stanowili pedagodzy pracujący na wsi $(41,4 \%)$, kolejna grupa pochodziła $\mathrm{z}$ miast powiatowych $(26,1 \%)$. Niska frekwencja dotyczyła miast wojewódzkich $(20,2 \%)$ i gminnych $(12,3 \%)$. Różnice dotyczyły również wieku i stażu pracy, a więc znaleźli się w grupie badanych zarówno nauczyciele młodzi, z krótkim stażem do 5 lat (48 osób), stażem 5-10 lat (75 osób), jak również bardzo doświadczeni - mający za sobą 10-15 lat pracy (131 osób), a nawet ponad 15-letni staż (519 osób). Warto podkreślić, że wśród respondentów aż $84 \%$ to nauczyciele $\mathrm{z}$ długim stażem pracy, a więc $\mathrm{z}$ dużym doświadczeniem zawodowym. Kolejnym znaczącym 
czynnikiem jest wykształcenie badanych: ponad 50\% respondentów to specjaliści w zakresie pracy z dziećmi ze SPE: oligofrenopedagodzy (173), pedagodzy (166), logopedzi (18), tyflopedagodzy (16), psychologowie (15), terapeuci pedagogiczni (15), socjoterapeuci (14). Na tej podstawie można wnioskować, że wyrażane w ankiecie opinie są głęboko przemyślane, poparte wiedzą i doświadczeniem pedagogicznym.

O gotowości nauczycieli do pracy w edukacji włączającej można wnioskować m.in. na podstawie ich opinii na temat zasadności kształcenia wszystkich dzieci bez względu na typ i rodzaj niepełnosprawności w jednej klasie.

\section{Czy zgadza się Pan/Pani z twierdzeniem, że wszystkie dzieci bez względu na typ, rodzaj niepełnosprawności, deficytów rozwojowych powinny uczyć się w jednej klasie?}

774 odpowiedzi

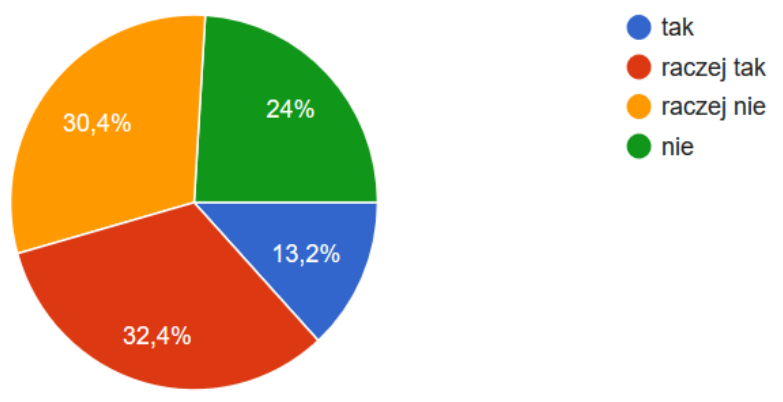

Ryc. 1. Diagram przedstawiający opinie respondentów na temat zasadności kształcenia w jednej klasie wszystkich dzieci bez względu na typ i rodzaj niepełnosprawności i deficytów rozwojowych

$\mathrm{Z}$ analizy powyższego diagramu wynika, że tylko $13,2 \%$ respondentów jest głęboko przekonanych o zasadności takiej formy kształcenia. Kolejne $32 \%$ swoją deklarację składa bez przekonania. Jednak 54\% sprzeciwia się takiej koncepcji powszechnej inkluzji.

Ciekawa może się okazać dodatkowo analiza argumentów uzasadniających wybory respondentów. Taką możliwość znajdujemy w kolejnym pytaniu badawczym: Czy uważa pan/pani, że każdy uczeń ze specjalnymi potrzebami powinien być uczniem klasy ogólnodostępnej w edukacji włączającej? Proszę uzasadnić swoją odpowiedź. Odpowiedź TAK zadeklarowało tylko 
$24 \%$ ankietowanych, NIE $65 \%$ ankietowanych, a $12 \%$ było niezdecydowanych. Poniżej przytoczone zostaną przykłady argumentów motywujących wybór odpowiedzi respondentów.

A. Odpowiedź TAK - argumenty:

- uczeń niepełnosprawny nie czuje się izolowany od swoich rówieśników;

- ze względu na naukę tolerancji i akceptacji wśród rówieśników ucznia niepełnosprawnego oraz możliwość jego przystosowania do życia w przyszłości;

- są to uczniowie w normie intelektualnej, stosują się do zasad w grupie, często są aktywni w różnych działaniach pozaedukacyjnych;

- wspólna edukacja uczy tolerancji, empatii;

- w zespole klasowym rozwijają się kontakty interpersonalne z rówieśnikami;

- uczniowie bez deficytów uczą się tolerancji dla odmienności, a uczeń z dysfunkcjami uczy się funkcjonować w otaczającej go rzeczywistości;

- dziecko ze specjalnymi potrzebami uczestniczy w całym procesie wychowawczym, a nie wybiórczo;

- stwarza to najpełniejszy rozwój ucznia z dysfunkcją na każdej płaszczyźnie;

- powinno się usuwać bariery, aby uczniowie mogli na miarę swoich możliwości osiągnąć sukces;

- wyrównują się szanse edukacyjne dla takiego ucznia, klasa wzmacnia działania ucznia i motywuje go do pracy;

- uczeń nabywa kompetencji społecznych.

B. Odpowiedź TAK, POD WARUNKIEM - argumenty:

- jeżeli szkoła dysponuje odpowiednimi zasobami - nauczycielami z kwalifikacjami i bazą materialną;

- jeżeli spełnione są wszystkie wymagania wobec ucznia, a świadomość nauczycieli jest na tyle duża, że pozwoli to na pozytywne jego oddziaływanie i usprawnianie wszelkich deficytów;

- pod warunkiem, że cała rada pedagogiczna jest przygotowana do podjęcia takiego wyzwania;

- w przypadku mało licznych klas;

- musi być zapewniona pomoc w organizacji kształcenia takiego ucznia poprzez zajęcia dodatkowe, nauczyciela wspomagającego, zatrudnienie psychologa, pedagoga na cały etat, logopedy;

C. Odpowiedź NIE - argumenty:

- uczeń w mniejszej klasie w szkole specjalnej osiągnąłby więcej;

- integracja nie działa dobrze na edukację uczniów z dysfunkcją i edukację dzieci zdrowych będących z nimi w klasie; 
- zależy to od indywidualnych potrzeb, umiejętności i możliwości ucznia;

- nie każda szkoła jest gotowa na przyjęcie ucznia niepełnosprawnego ruchowo, brak dostosowań architektonicznych;

- każdy przypadek powinien być rozpatrywany indywidualnie;

- nie na wszystkich uczniów ze specjalnymi potrzebami edukacyjnymi klasa ma pozytywny wpływ;

- uczniowie niepełnosprawni nie odnajdą się, nawet jeżeli zatrudnimy najlepszych specjalistów, w szkole ogólnodostępnej;

- są uczniowie, którzy osiągają o wiele lepsze wyniki nauczania w szkołach specjalnych, tam są też dobrze przygotowani nauczyciele. Uczniowie ci otrzymują pomoc wszechstronną od wielu specjalistów;

- nie każdy uczeń z SPE jest w stanie zrozumieć materiał i nadążać za programem nauczania, nieliczni posiadają takie umiejętności;

- są zbyt duże dysproporcje wśród uczniów i fizyczna niemożliwość w realizacji materiału;

- w przypadku niepełnosprawności sprzężonych, jak autyzm z upośledzeniem umysłowym w stopniu umiarkowanym i uczniów zagrożonych niedostosowaniem społecznym, szkoła często nie ma możliwości pomocy i środków;

- uczeń ma mniejszą szansę na zmniejszenie swoich deficytów;

- są deficyty uczniów wykluczające ich z możliwości pracy i działania w klasie ogólnodostępnej;

- szkoły ogólnodostępne nie są w stanie zapewnić uczniom w takim stopniu pomocy, w jakim to czynią specjalistyczne ośrodki;

- są przypadki tak trudne i sytuacje tak skomplikowane, że będzie to ciężar nie do pokonania w szkole ogólnodostępnej;

- zależy to od zaleceń poradni psychologiczno-pedagogicznej, czasem dla dobra i poczucia komfortu dzieci ze specjalnymi potrzebami edukacyjnymi powinny uczyć się w placówkach specjalnych;

- szkoła nie posiada specjalistów do wszystkich niepełnosprawności ewentualnych uczniów;

- są uczniowie, którzy mogą pracować tylko w określonych warunkach w małym zespole i przy obecności nauczyciela wspomagającego;

- fizyczne funkcjonowanie nie jest samodzielne;

- poziom demoralizacji osób jest tak duży, że powinni być resocjalizowani;

- brak wykwalifikowanej kadry pedagogicznej;

- dezorganizuje to pracę z innymi uczniami podczas lekcji;

- niektóre niepełnosprawności utrudniają pracę z pozostałymi uczniami; 
- zagraża bezpieczeństwu innym dzieciom, a często swojemu;

- wymaga indywidualnego nauczania;

- niekiedy niepełnosprawność jest na tyle głęboka, że nie pozwala na organizowanie edukacji w szkole;

- niektóre dzieci wymagają stosowania odmiennych metod i technik wychowawczych;

- bywa, że obecność pełnosprawnych uczniów utrudnia przyswajanie wiedzy;

- brak odpowiednich kwalifikacji personelu, środków dydaktycznych, bariery;

- zbyt duża liczba uczniów w klasie;

- uczeń w specjalnym ośrodku czuje się lepiej, może tam być bardzo dobrym uczniem;

- zależy to nie tylko od zdiagnozowanych deficytów, ale również od współpracy z domem rodzinnym i zaangażowaniem rodziców;

- brak czasu na całkowite zaspokojenie jego potrzeb, jak również potrzeb klasy (hałas, rozkojarzenie dzieci pełnosprawnych);

- stanowią zagrożenie dla siebie i innych;

- decyzja powinna należeć do rodzica, który w porozumieniu ze specjalistą będzie w stanie podjąć właściwą decyzję;

- osiągnęliby większy sukces w ośrodkach szkolno-wychowawczych, w których pracują specjaliści z różnych dziedzin. Jest ich dużo, mają większe doświadczenie w pomocy dziecku.

O zaletach edukacji włączającej mówi się i pisze dużo. Przytoczone argumenty wyrażające aprobatę dla działań na rzecz inkluzji są odzwierciedleniem realnych korzyści, jakie może czerpać każdy uczeń ze współpracy z innymi, jakże różniącymi się od siebie wzajemnie rówieśnikami. Na uwagę zasługuje fakt, że największy nacisk nauczyciele kładli na korzyści w obszarze relacji rówieśniczych. Podkreślali też, że warunkiem sukcesu jest dobre przygotowanie szkoły do podjęcia takiego wyzwania.

Negatywne opinie nauczycieli można podzielić na dwie kategorie:

a) związane $z$ organizacją formalną edukacji włączającej, np. niedostosowanie liczebne klas, brak specjalistów, w tym brak nauczycieli wspomagających;

b) związane $\mathrm{z}$ indywidualnymi potrzebami konkretnych uczniów, np. nie dla każdego ucznia kształcenie w szkole ogólnodostępnej jest korzystne, dla niektórych dużo korzystniejsze warunki może zapewnić szkoła specjalna; innym często powtarzającym się argumentem jest konflikt interesów poszczególnych uczniów, zbyt duże dysproporcje w możliwościach edukacyjnych, 
wzajemne utrudnianie sobie nauki, dezorganizacja lekcji, trudności wychowawcze.

Świadomość utrudnień i zagrożeń obniża gotowość nauczycieli do podejmowania tego wyzwania. Praca z grupą zróżnicowaną wymaga od pedagoga dużego wysiłku i zaangażowania, długiego czasu na przygotowanie i realizację zadań dydaktycznych. O wiele łatwiej byłoby udźwignąć ten ciężar przy dobrze rozwiniętym systemie motywacyjnym. Niestety polski nauczyciel ma znacznie niższe poczucie prestiżu swojego zawodu niż pedagodzy w większości krajów europejskich. Do tego ma niskie zarobki, czuje się przeciążony pracą, a jednocześnie oceniany przez społeczeństwo i zagrożony utratą pracy (Chrzanowska 2019a, s. 256; 2019b, s. 52). Czy w takiej sytuacji można znaleźć motywację do działania? Czy można czerpać satysfakcję z wykonywanej pracy?

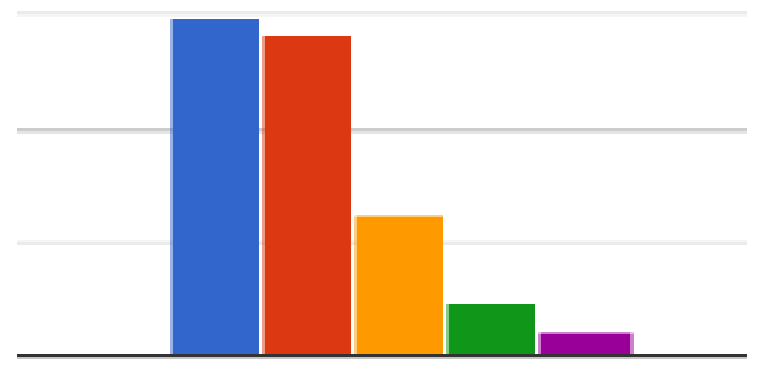

I 5 Całkowicie się zgadzam

I 4 Częściowo się zgadzam

- 3 Nie mam zdania

I 2 Częściowo się nie zgadzam

I I Całkowicie się nie zgadzam

Ryc. 2. Wykres przedstawiający opinie respondentów dotyczące twierdzenia: Praca z dziećmi ze specjalnymi potrzebami edukacyjnymi jest satysfakcjonujaca

Na podstawie prezentowanych badań odpowiedź na to pytanie okazuje się optymistyczna. Polscy respondenci w zdecydowanej większości przyznali, że praca $z$ dziećmi ze specjalnymi potrzebami edukacyjnymi może być i jest satysfakcjonująca. Ta deklaracja daje nadzieję, że idea włączania zakorzenia się coraz głębiej w świadomości nauczycieli, że pomimo stawianych przed 
nimi ambitnych wyzwań, pomimo doświadczanych trudności i ograniczeń, pomimo niedoskonałej jeszcze organizacji pracy szkoły i nauczyciela, praca ta jest i może być satysfakcjonująca dla zdecydowanej większości respondentów.

\section{DYSKUSJA I WNIOSKI KOŃCOWE}

1. Interpretujac opisane tu wyniki, warto je zestawić z innymi badaniami prowadzonymi w ostatnich latach. Zastanawia fakt, że wyniki przedstawione powyżej są bardziej pesymistyczne niż inne w aspekcie aprobaty eduakcji włączającej. Poziom aprobaty jest niski (45\%). Z. Gajdzica (2013) po drugiej serii swoich badań zauważył przyrost poczucia przygotowania nauczycieli szkół ogólnodostępnych do pracy z uczniem niepełnosprawnym między rokiem 2006 a 2012. W opublikowanych w roku 2019 doniesieniach z badań I. Chrzanowskiej (2019, s. 330), na pytanie: Czy edukacja włączjąca jest dobrym rozwiązaniem dla różnych grup uczniów, tj. dla:

a) uczniów sprawnych - twierdząco odpowiedziało $72 \%$ nauczycieli z placówek ogólnodostępnych, $70 \%$ z placówek integracyjnych i 48,5\% ze specjalnych;

b) uczniów z zaburzeniami rozwoju - twierdząco odpowiedziało 77,5\% nauczycieli z placówek ogólnodostępnych, 78,6\% z placówek integracyjnych i tylko $33,6 \%$ ze specjalnych;

c) uczniów zdolnych - twierdząco odpowiedziało $62,7 \%$ nauczycieli z placówek ogólnodostępnych, 66,5\% z placówek integracyjnych i tylko $42,9 \%$ ze specjalnych.

Można się zastanawiać, skąd tak duża rozbieżność (około 45\% łącznie odpowiedzi „tak” i „raczej tak” w badaniach autorki). Wymaga to na pewno dalszych badań porównawczych. Jednym z czynników różnicujących mogło być rozczłonkowanie pytań na różne grupy uczniów. Tym bardziej, że ta sama autorka pytała respondentów, które grupy uczniów z zaburzeniami mają $\mathrm{w}$ ich opinii szansę na powodzenie w edukacji włączającej, i okazuje się, że panuje duża jednomyślność $\mathrm{w}$ tej kwestii wśród nauczycieli różnych typów szkół. Jako grupy z największymi szansami na powodzenie w edukacji włączjącej wymieniali uczniów:

a) z niepełnosprawnością ruchową;

b) słabosłyszących;

c) z lekką niepełnosprawnościa intelektualną;

d) słabowidzących; 
e) przewlekle chorych;

f) z zespołem Aspergera.

Najniższe szanse przypisywano uczniom z umiarkowaną i znaczną niepełnosprawnością intelektualną (Chrzanowska 2019a, s. 332). Te wyniki byłyby zbieżne z głównymi argumentami nauczycieli przeciwko edukacaji włączającej, a mianowicie, że nie dla każdego ucznia kształcenie w szkole ogólnodostępnej jest korzystne. Charakterystyka opinii nauczycieli na temat szans edukacyjnych poszczególnych grup uczniów pomaga zrozumieć i wyjaśnić, dlaczego tak niewielu zdecydowało się na odpowiedź zdecydowanie twierdzącą w odniesieniu do całej populacji uczniowskiej.

2. Analiza argumentów ZA i PRZECIW edukacji włączjącej pozwoliła sformułować następujące wnioski:

A. Wśród korzyści płynących z edukacji włączjącej najczęściej wymieniano uspołecznienie i rozwój relacji rówieśniczych. Wyniki te są porównywalne do badań J. Skibskiej (2016), w których nauczyciele jako najwyższą wartość edukacji włączającej wymienili uspołecznienie (40,5\%) oraz kontakt z grupą rówieśniczą $(42,2 \%)$. Dostrzec więc można w tym aspekcie spójność niezależnie prowadzonych badań.

B. Wśród zagrożeń wskazywano czynniki wynikające z formalnej organizacji edukacji, np. liczebności klas czy braku specjalistów, a także indywidualnych potrzeb konkretnych uczniów, którym placówka ogólnodostępna nie w każdym przypadku jest w stanie zapewnić optymalne warunki do rozwoju lub warunki panuajce w klasie utrudniają wykorzystanie pełni potencjału rozwojowego wszystkim uczniom.

Bardzo podobne czynniki kształtujące nieprzychylne postawy nauczycieli wobec inkluzji zostały sformułowane również w innych badaniach (Chrzanowska 2019b, s. 45-46; 2019a, Skibska 2016, Gajdzica 2013).

3. Z zaprezentowanych badań opinii nauczycieli można wyciągnąć wnioski dla dalszych działań edukacyjnych. Dojrzewanie gotowości nauczycieli do pracy $\mathrm{z}$ grupą zróżnicowaną $\mathrm{w}$ inkluzji wymaga budowania systemu, w którym nauczyciel będzie czuł się docenianym społecznie profesjonalistą, kompetentnym przewodnikiem i będzie otoczony siecią wsparcia, z którego w każdej chwili może skorzystać. Warto budować silne zaplecze metodyczne i specjalistyczne dla nauczyciela. Już dziś można wskazać przykłady takich działań.

Systematycznie ukazują się publikacje o charakterze metodycznym, np. Krakowiak (red.) (2017), Diagnoza specjalnych potrzeb rozwojowych i edukacyjnych dzieci i mtodzieży. Standardy, wytyczne oraz wskazówki do przy- 
gotowywania $i$ adaptacji narzędzi diagnostycznych dla dzieci i młodzieży $z$ wybranymi specjalnymi potrzebami rozwojowymi i edukacyjnymi; Krakowiak (2019) Niepetnosprawni we wspólnocie zmierzajacej do solidarności $i$ odpowiedzialności; opracowanie pod kierunkiem A. Dłużniewskiej (2018) Praca z uczniami ze specjalnymi potrzebami edukacyjnymi w szkołach ogólnodostępnych. Realizacja podstawy programowej ksztatcenia ogólnego na II etapie edukacyjnym. Koncepcja szkolenia oraz materiaty merytoryczne stużace podnoszeniu kompetencji nauczycieli języka polskiego.

Popularyzowanie dobrych praktyk jest działaniem pożądanym przez nauczycieli. Potrzebują oni lekcji pokazowych, superwizji. Jako przykłady działań w tym obszarze można podać chociażby rozwijanie inicjatywy tworzenia szkół ćwiczeń (Wspieranie tworzenia szkół ćwiczeń 2018; Tarwacki 2015). Ośrodek Rozwoju Edukacji (ORE) realizuje od kilku lat projekt: Bank dobrych praktyk, w ramach którego można zgłosić własne dobre praktyki, ale też zapoznać się z ofertą innych szkół (Bank Dobrych Praktyk na ore.edu.pl, dostęp: 11.07.2020). W każdym województwie zostali również wyłonieni i przeszkoleni liderzy w ramach projektu Liderzy edukacji włączajacej, których zadaniem jest prowadzić szkolenia i porady z tego zakresu na terenie swojego województwa. Na etapie opracowywania modelu jest również projekt tworzenia Specjalistycznych Centrów Wsparcia Edukacji Wtaczającej (Tomaszewska 2019), które mają szansę powstawać na bazie szkół specjalnych jako zaplecze specjalistyczne dla szkół ogólnodostępnych.

Przemiany w zakresie postaw nauczycieli wobec upowszechniającej się idei edukacji włączającej są zauważalne od około ostatnich dziesięciu lat i ewoluują od postaw nieuzasadnionej niechęci, sprzeciwu wobec obecności dziecka z trudnościami i niepełnosprawnościami w klasie do postawy otwartej, wskazującej na trudności i ograniczenia, które w sposób systemowy lub niesystemowy należy przezwyciężać, aby inkluzja miała coraz pełniejszy i satysfakcjonujący wymiar dla wszystkich uczestników triady UCZEŃ RODZIC - NAUCZYCIEL. Niewątpliwie nauczyciel jest najważniejszym jej ogniwem. Dlatego diagnoza postaw nauczycieli oraz ich potrzeb musi skłaniać do systematycznych działań wzmacniających i wspierających nauczyciela w tym odpowiedzialnym zadaniu.

\section{BIBLIOGRAFIA}

Bank Dobrych Praktyk, https://www.ore.edu.p1/2011/07/specjalne-potrzeby-edukacyjne-bank-do brych-praktyk/ (dostęp: 11.07.2020). 
BARTUŚ, E. (2014). Integralna działalność nauczyciela w pracy z uczniem ze specjalnymi potrzebami edukacyjnymi. W: J. WYCZESANY (red.), Dydaktyka specjalna - wybrane zagadnienia, (s. 197-210). Gdańsk: Harmonia Universalis.

Biatek, K., JarmuŻ, M., OŚKo, A. (2015). Międzykulturowość w szkole. Poradnik dla nauczycieli i specjalistów. Warszawa: ORE.

Celuch, M. (2019). Nauczyciel wspomagający w szkole, przedszkolu, ośrodku. Warszawa: OŚWIATA Grupa Wydawnicza.

Chrzanowska, I. (2010). Problemy edukacji dzieci i młodzieży z niepetnosprawnościa. Regionalna specyfika czy ogólnopolska tendencja. Kraków: Impuls.

CHRZANOWSKA, I. (2016). Opinie nauczycieli szkót specjalnych na temat edukacji właczajacejuczeń ze SPE w szkole właczającej (s. 55-74), https://repozytorium.amu.edu.pl/bitstream/ 10593/19552/1/SE_41_2016_Iwona_Chrzanowska.pdf (dostęp: 10.07.2020).

ChrzANowsKA, I. (2018). Edukacja włączająca - wyzwanie dla kompetencji pedagogów specjalnych. Studia Edukacyjne, 48, 23-32.

ChrZANOWSKA, I. (2019a). Nauczyciele o szansach i barierach edukacji włączajacej. Warszawa: PWN.

Chrzanowska, I. (2019b). Postawy wobec edukacji włączającej - jakie skutki? W: I. CHRZANOWSKA. G. SZUMSKI (red.), Edukacja włączająca w przedszkolu i szkole (s. 44-53). Warszawa: Wydawnictwo FRSE.

Chrzanowska, I., Szumski, G. (2019). Kompetencje zawodowe - jakie wyzwania? W: I. CHRZANOWSKA, G. SZUMSKI (red.), Edukacja włączajaca w przedszkolu i szkole (s. 54-61). Warszawa: Wydawnictwo FRSE.

Cytowska, B. (2016). Przegląd badań empirycznych nad inkluzją w edukacji. Problemy Edukacji, Rehabilitacji i Socjalizacji Osób Niepetnosprawnych, 22(1), 189-213.

DRYŻAŁOWSKA, G. (2007). Rozwój językowy dziecka z uszkodzonym stuchem a integracja edukacyjna: model ksztalcenia integracyjnego. Warszawa: Wydawnictwa UW.

Europejska Agencja do spraw Specjalnych Potrzeb i Edukacji WŁąCZającej (2019). Wsparcie podnoszenia jakości edukacji włączającej w Polsce. Rekomendacje i działania priorytetowe. https://www.gov.pl/web/edukacja/projekt-realizowany-w-ramach-program-wsparcia -reform-strukturalnych (dostęp: 11.07.2020).

Europejska Agencja dS. Specjalnych PotrZeb i Edukacji WŁącZającej (2014). Pięć kluczowych przesłań dla edukacji włączającej. Od teorii do praktyki. Odense, Dania: Europejska Agencja ds. Specjalnych Potrzeb i Edukacji Włączającej.

Europejska Agencja Rozwoju Edukacji Uczniów ze Specjalnymi Potrzebami (2011). Ksztatcenie nauczycieli przygotowujace do edukacji wtaczajacej - wyzwania $i$ szanse. Odense, Dania: Europejska Agencja Rozwoju Edukacji Uczniów ze Specjalnymi Potrzebami.

Europejska Agencja Rozwoju Edukacji Uczniów ze Specjalnymi Potrzebami (2012). Profil nauczyciela edukacji włączającej. Odense, Dania: Europejska Agencja Rozwoju Edukacji Uczniów ze Specjalnymi Potrzebami.

GAJDZICA, Z. (2013), Nauczyciele szkoły ogólnodostępnej o swoim przygotowaniu do pracy $\mathrm{z}$ uczniem niepełnosprawnym w kontekście przemian pierwszej dekady XXI wieku. Chowanna, 2, 263-273.

GRYGIER, U. (2019). Edukacja właczająca $w$ aspekcie organizacji pomocy psychologiczno-pedagogicznej i kształcenia specjalnego. $Z$ doświadczeń szkoły. Warszawa: ORE.

https://www.ore.edu.pl/2017/11/bank-dobrych-praktyk-materialy-do-pobrania/ (dostęp: 11.07.2020). 
JACHIMCZAK, B. (2018). Kształcenie nauczycieli dla edukacji włączającej. Studia Edukacyjne, 48, $33-43$.

JACHIMCZAK, B. (2019). Nauczyciel w edukacji włączającej. W: I. ChrZANOwSKA. G. SzUMSKI (red.), Edukacja włączająca w przedszkolu i szkole (s. 44-53). Warszawa: Wydawnictwo FRSE.

KRAKOWIAK, K. (2019). Niepetnosprawni we wspólnocie zmierzającej do solidarności i odpowiedzialności. Lublin: Wydawnictwo KUL,

KRAKOWIAK, K. (red.) (2017). Diagnoza specjalnych potrzeb rozwojowych i edukacyjnych dzieci i młodzieży. Standardy, wytyczne oraz wskazówki do przygotowywania i adaptacji narzędzi diagnostycznych dla dzieci i młodzieży z wybranymi specjalnymi potrzebami rozwojowymi i edukacyjnymi. Warszawa: ORE.

Liderzy edukacji właczającej, https://www.ore.edu.pl/2017/11/liderzy-edukacji-wlaczajacej/ (dostęp: 11.07.2020).

MAKARUK, A.R. (2011). Repertuar oddziaływań nauczycielskich służących rozwijaniu potencjału informatycznego uczniów gimnazjum. W: W. LiMONT, J. CieŚLIKOwSKA, D. JASTRZĘBSKA (red.), Zdolni w szkole, czyli o zagrożeniach i możliwościach rozwojowych uczniów zdolnych. Poradnik dla nauczycieli i wychowawców (s. 168-173). Warszawa: ORE.

Praca z uczniami ze specjalnymi potrzebami edukacyjnymi w szkołach ogólnodostępnych. Realizacja podstawy programowej kształcenia ogólnego na II etapie edukacyjnym. Koncepcja szkolenia oraz materiaty merytoryczne stużace podnoszeniu kompetencji nauczycieli języka polskiego (2018). Oprac. A. Dłużniewska. Warszawa: ORE.

SKIBSKA, J. (2016). Edukacja włączająca w opinii nauczycieli edukacji wczesnoszkolnej - analiza segmentacyjna. Doniesienia z badań. W: Z. GAJDZICA, M. BEŁZA (red.), Inkluzja edukacyjna Idee, teorie, koncepcje, modele edukacji właczajacej a wybrane aspekty praktyki edukacyjnej, (s. 161-174). Katowice: Wydawnictwo UŚ.

Skotnicka, B. (2016). Wsparcie społeczne nauczycieli edukacji inkluzyjnej. Problemy Edukacji, Rehabilitacji i Socjalizacji Osób Niepetnosprawnych, 22(1), 175-87.

Specjalne potrzeby edukacyjne dzieci i młodzieży. Prawne ABC dyrektora przedszkola, szkoly i placówki (2010). Warszawa: MEN

SzCZEPKOwSKA, K. (2019). Edukacja właczajaca w szkole - szanse i wyzwania. Warszawa: ORE.

SzCZEPKOWSKA, K. (2019). Wspótpraca z rodzicami, czyli jak rozmawiać o edukacji włączającej. Warszawa: ORE.

Szumski, G. (2019). Zróżnicowane grupy uczniów - jakie problemy? W: I. CHRZANowsKA. G. SZUMSKI (red.), Edukacja właczająca w przedszkolu i szkole (s. 62-69). Warszawa: Wydawnictwo FRSE.

TARWACKI, M. (2015). Edukacja właczająca-przyszłość polskiej edukacji. Warszawa: ORE.

TOMASZEwSKA, A. (2019). Nowa rola placówek specjalnych. W: I. CHRZANOWSKA. G. SZUMSKI (red.), Edukacja właczająca w przedszkolu i szkole (s. 264-275). Warszawa: Wydawnictwo FRSE.

Wspieranie tworzenia szkót ćwiczeń (2018). Warszawa: ORE.

ZADĘCKA, E. (2019). Edukacja właczająca $w$ aspekcie organizacji pomocy psychologiczno-pedagogicznej i ksztatcenia specjalnego. $Z$ doświadczeń poradni psychologiczno-pedagogicznej. Warszawa: ORE. 


\title{
GOTOWOŚĆ NAUCZYCIELI DO PRACY W SYSTEMIE EDUKACJI WŁĄCZAJĄCEJ
}

\begin{abstract}
STRESZCZENIE
Jesteśmy świadkami przemian w edukacji zmierzających do upowszechnienia kształcenia uczniów w systemie edukacji włączającej. Proces ten trwa w całej Europie i ma charakter nieodwracalny. Edukacja włączająca w niektórych szkołach jest już rzeczywistością, w innych dość odległą ideą. Celem artykułu jest charakterystyka procesu dojrzewania gotowości nauczycieli do pracy w systemie edukacji włączającej na tle przemian dokonujących się w edukacji w ostatnim dziesięcioleciu. W artykule został zaprezentowany wizerunek, profil idealnego nauczyciela edukacji włączającej z uwzględnieniem jego cech osobowości, predyspozycji do zawodu, następnie jego kwalifikacji i kompetencji, aż wreszcie praktycznych umiejętności. W drugiej części autorka dokonała prezentacji fragmentu współautorskich badań przeprowadzonych w 2019 r. wśród ponad 700 nauczycieli różnych typów szkół i poziomów edukacji, konfrontując je z innymi badaniami nauczycieli w kraju i za granicą. Badania dotyczą opinii nauczycieli na temat edukacji włączającej oraz doświadczanych przez nich trudności i potrzeb na drodze do realizacji skutecznej inkluzji. Podsumowaniem będzie nakreślenie kierunków przemian i dobrych praktyk w zakresie przygotowania nauczycieli do kompetentnej i efektywnej pracy w nurcie edukacji włączającej.
\end{abstract}

Słowa kluczowe: edukacja włączająca; uczeń ze specjalnymi potrzebami edukacyjnymi; grupa zróżnicowana; gotowość nauczycieli; wizerunek idealnego nauczyciela; trudności i potrzeby wsparcia nauczycieli.

\section{TEACHERS' READINESS TO WORK IN INCLUSIVE EDUCATION}

\section{SUMMARY}

We are witnessing changes in education aimed at popularising the education of students in the inclusive education system. This process is ongoing across Europe and is irreversible. Inclusive education has already become a reality in some schools yet in others it is rather a far-fetched idea. The aim of the article is to characterize the process of developing readiness of teachers to work in the inclusive education system in the light of changes in education over the past decade.

The article will present the image, profile of an ideal teacher of inclusive education taking into account his personality traits, predisposition to the profession, then qualifications and competences, and finally practical skills. In the second part, the author will present an excerpt from a co-author's research conducted in 2019 on more than 700 teachers of different types of schools and levels of education in comparison with other Polish and international studies related to teachers. The research pertains to teachers' opinions on inclusive education and the difficulties and needs they experience on the way to effective inclusion. The summary will outline the directions of changes and good practices in preparing teachers for competent and effective work in the inclusive education.

Key words: inclusive education; student with special educational needs; diverse group; teachers' readiness; image of the ideal teacher; difficulties and needs for teacher support. 